Dermatology 2008;217:201-202

DOI: $\underline{10.1159 / 000141651}$

\section{Investigation of +405 and -460 Polymorphisms of Vascular Endothelial Growth Factor in Psoriasis and Short-Term Responsiveness to Efalizumab Therapy}

I. Stefanaki, G. Dimisianos, C. Antoniou, A. Katsambas, A. Stratigos

Department of Dermatology, Andreas Sygros Hospital, University of Athens, Athens, Greece

Key Words

Psoriasis - Vascular endothelial growth factor - Efalizumab

\section{Introduction}

Psoriasis is a chronic autoimmune disorder with cutaneous manifestations. The two major pathological lesions in psoriasis are epidermal hyperproliferation with abnormal differentiation, and inflammatory infiltration in the dermal and epidermal layers [1]. Angiogenesis also plays an important role in psoriasis. Vascular endothelial growth factor (VEGF), a principal angiogenic factor, is produced by keratinocytes as well as peripheral blood mononuclear cells. VEGF is found at increased levels in psoriatic plaques compared with normal skin, and its levels are associated with the severity of the disease [2-4]. Two VEGF single nucleotide polymorphisms (SNP), at positions +405 and -460 from transcription start, have been associated with early-onset [5] and lateonset psoriasis [6], respectively, and may have significant genetic control over VEGF production in psoriasis.

Efalizumab is a humanized monoclonal IgG1 antibody that binds with high affinity to CD11a, the $\alpha$ subunit of LFA-1 (leukocyte function-associated antigen 1). It targets psoriasis pathogenesis at multiple levels, including the inhibition of T cell binding with endothelial cells and their migration to the site of cutaneous inflammation [7]. Given the role of VEGF in leukocyte trafficking in psoriasis and the inhibitory effect of efalizumab, we hypothesized that genetic control of VEGF production by specific SNP could influence the response of psoriasis to efalizumab therapy. We studied +405 and -460 VEGF polymorphisms in a group of psoriasis patients treated with efalizumab in order to investigate whether these polymorphisms are associated with: (1) early- or late-onset chronic plaque psoriasis and with other disease characteristics, and (2) with the response of psoriasis patients to efalizumab therapy.

\section{Patients and Methods}

Forty-four adult patients with chronic plaque psoriasis who had been or were currently being treated with efalizumab at the University Clinic of Dermatology, A. Sygros Hospital, were enrolled in the study. All of these patients had received systemic therapy prior to their treatment with efalizumab. A response to efalizumab or other systemic treatment was defined as a decrease of at least $75 \%$ in the pre-treatment Psoriasis Area and Severity Index score (PASI 75) after 3 months of therapy.
After informed consent, genomic DNA was isolated from whole blood of the patients. The research protocol was approved by the A. Sygros Hospital Institutional Review Board, and Declaration of Helsinki protocols were followed.

The +405 and -460 VEGF genotypes were studied using PCR restriction fragment length polymorphism (PCR-RFLP) as described previously [5]. Our primary objective was to compare VEFG polymorphisms in responders versus non-responders, and the secondary endpoints were to investigate whether these polymorphisms had any implications upon the age of onset, family history of psoriasis, history of guttate psoriasis and nail involvement.

\section{Statistical Analysis}

Comparisons of disease duration among genotype categories were performed using the Kruskal-Wallis test. Pairwise multiple comparisons were performed using the Mann-Whitney test. In order to examine the correlation of genotypes with categorical demographic and disease characteristics, $\chi^{2}$ or Fisher's exact tests were used. All tests were two-sided, and statistical significance was set at $\mathrm{p}<0.05$.

\section{Results and Discussion}

Forty-four patients participated in the study [27 males (61.4\%) and 17 females (38.6\%); 12 (27.3\%) with early-onset and $32(72.7 \%)$ with late-onset psoriasis]. The distribution of +405 and -460 VEGF genotypes among our patients is presented in table 1 . The results of our study did not indicate an association between the VEFG genotype and short-term response (at 3 months) to efalizumab (23 efalizumab responders, 21 non-responders) or other systemic therapy (tables 2, 3). Furthermore, we did not find any correlation between these genotypes and other parameters that were also studied, such as age at onset of psoriasis, disease duration, family history of psoriasis, patient history of guttate psoriasis and nail involvement (data not shown).

Psoriasis often presents therapeutical problems, since most systematic agents require prolonged usage, during which they can cause adverse events. Therefore, prognostic markers that predict therapeutic outcomes would be of significant value. In this study, we examined the role of +405 and -460 VEGF polymorphisms with regards to their association with disease characteristics and with the outcome of efalizumab treatment. Both these SNP have been associated with early-onset [5] and late-onset psoriasis [6]. Further-

Table 1. Distribution of genotypes

\begin{tabular}{llrl}
\hline Polymorphism & Genotype & $\mathrm{n}$ & $\%$ \\
\hline+405 & CC & 7 & 15.9 \\
& CG & 31 & 70.5 \\
& GG & 6 & 13.6 \\
\hline-460 & TT & 18 & 40.9 \\
& CC & 4 & 9.1 \\
& CT & 22 & 50.0 \\
\hline
\end{tabular}

\section{KARGER}

(ㄷ) 2008 S. Karger AG, Basel

Fax +41 613061234 E-Mail karger@karger.ch www.karger.com www.karger.com/drm 
Table 2. Correlation between polymorphism +405 and treatment response

\begin{tabular}{|c|c|c|c|c|c|c|c|}
\hline & \multicolumn{2}{|c|}{$\mathrm{CC}$} & \multicolumn{2}{|c|}{ CG } & \multicolumn{2}{|c|}{ GG } & \multirow{2}{*}{$\begin{array}{l}\mathrm{p} \\
\text { value }\end{array}$} \\
\hline & $\mathrm{n}$ & $\%$ & $\mathrm{n}$ & $\%$ & $\mathrm{n}$ & $\%$ & \\
\hline Efalizumab & 4 & 57.1 & 16 & 51.6 & 3 & 50.0 & 0.959 \\
\hline Ciclosporin & 1 & 25.0 & 16 & 61.5 & 3 & 60.0 & 0.385 \\
\hline Acitretin & 1 & 50.0 & 3 & 27.3 & 3 & 100.0 & 0.078 \\
\hline $\begin{array}{l}\text { Methotrexate/ } \\
\text { ultraviolet B }\end{array}$ & 4 & 57.1 & 20 & 64.5 & 4 & 66.7 & 0.922 \\
\hline
\end{tabular}

$\mathrm{n}=$ Number of responders to therapy.

Table 3. Correlation between polymorphism -460 and treatment response

\begin{tabular}{|c|c|c|c|c|c|c|c|}
\hline & \multicolumn{2}{|c|}{$\mathrm{TT}$} & \multicolumn{2}{|c|}{$\mathrm{CC}$} & \multicolumn{2}{|c|}{$\mathrm{CT}$} & \multirow{2}{*}{$\begin{array}{l}\mathrm{p} \\
\text { value }\end{array}$} \\
\hline & $\mathrm{n}$ & $\%$ & $\mathrm{n}$ & $\%$ & $\mathrm{n}$ & $\%$ & \\
\hline Efalizumab & 10 & 55.6 & 2 & 50.0 & 11 & 50.0 & 0.936 \\
\hline Ciclosporin & 7 & 50.0 & 2 & 100.0 & 11 & 57.9 & 0.407 \\
\hline Acitretin & 1 & 20.0 & 2 & 100.0 & 4 & 44.4 & 0.156 \\
\hline $\begin{array}{l}\text { Methotrexate/ } \\
\text { ultraviolet B }\end{array}$ & 10 & 55.6 & 4 & 100.0 & 14 & 63.6 & 0.247 \\
\hline
\end{tabular}

$\mathrm{n}=$ Number of responders to therapy.

more, VEGF production by peripheral blood mononuclear cells in psoriasis is determined by genotype; $-460 \mathrm{CC}$ and $+405 \mathrm{GG}$ genotypes are 'low VEGF producers', whereas $-460 \mathrm{TT}$ and $+405 \mathrm{CC}$ genotypes are 'high VEGF producers' [8]. Finally, the VEGF -460 TT genotype has been associated with the non-response of psoriasis to acitretin treatment, while patients with the -460 TC genotype are twice as likely to respond to acitretin therapy $[5,8]$.

The effect of VEGF on leukocyte recruitment or efalizumab action has not been clearly established. Various adhesion molecules have been implicated in T lymphocyte binding to dermal vascular endothelium in psoriasis, but the chemotactic signals that promote subsequent movement into the adjacent dermis and overlying epidermis are poorly defined. Studies have shown enhanced expression of E-selectin, cutaneous lymphocyte antigen LFA-1, ICAM-1 (intercellular adhesion molecule-1) and other adhesion molecules in psoriatic skin [9]. Keratinocytes of patients with psoriasis show an intrinsically abnormal chemokine production profile, such as high levels of interleukin 8, monocyte chemoattractant protein 1 (MCP-1) and IFN- $\gamma$-induced protein of $10 \mathrm{kd}$ (IP-10), and may thus favor the recruitment of distinct leukocyte subsets into the skin $[10,11]$. In the livers of cirrhotic rats, cirrhosis progression was associated with a significant enhancement in vascular density and expression of VEGF-A, and the newly formed hepatic vasculature expressed vascular cellular adhesion molecule 1 and ICAM-1 [12]. Data from other experiments suggest that the inflammation that occurs during VEGFinduced pathological brain angiogenesis plays a contributory role in the pathological angiogenic process [13].
In this study, we have shown that +405 and -460 VEGF polymorphisms do not affect or predict the response of psoriasis to efalizumab. We also failed to show any association between these polymorphisms and age of disease onset, or the treatment response to acitretin reported by other studies. This could be due to the relatively small number of patients we studied, or to the action of other, currently unknown, factors contributing to the psoriasis phenotype and response to therapy. Further studies and large cohorts of patients are required to reach firm conclusions.

\section{References}

1 Creamer D, Allen MH, Sousa A, Poston R, Barker JN: Localization of endothelial proliferation and microvascular expansion in active plaque psoriasis. Br J Dermatol 1997;136:859-865.

- 2 Detmar M, Brown LF, Claffey KP, Yeo KT, Kocher O, Jackman RW, Berse B, Dvorak HF: Overexpression of vascular permeability factor/ vascular endothelial growth factor and its receptors in psoriasis. J Exp Med 1994;180:1141-1146.

- 3 Creamer D, Allen MH, Groves RW, Barker JN: Circulating vascular permeability factor/vascular endothelial growth factor in erythroderma. Lancet 1996;348:1101

4 Bhushan M, McLaughlin B, Weiss JB, Griffiths CE: Levels of endothelial cell stimulating angiogenesis factor and vascular endothelial growth factor are elevated in psoriasis. Br J Dermatol 1999;141:1054-1060.

5 Young HS, Summers AM, Bhushan M, Brenchley PE, Griffiths CE: Single-nucleotide polymorphisms of vascular endothelial growth factor in psoriasis of early onset. J Invest Dermatol 2004;122:209-215.

-6 Barile S, Medda E, Nistico L, Bordignon V, Cordiali-Fei P, Carducci M, Rainaldi A, Marinelli R, Bonifati C: Vascular endothelial growth factor gene polymorphisms increase the risk to develop psoriasis. Exp Dermatol 2006; 15:368-376.

7 Jullien D, Prinz JC, Langley RG, Caro I, Dummer W, Joshi A, Dedrick $R$, Natta P: T-cell modulation for the treatment of chronic plaque psoriasis with efalizumab (Raptiva): mechanisms of action. Dermatology 2004;208:297-306.

-8 Young HS, Summers AM, Read IR, Fairhurst DA, Plant DJ, Campalani E, Smith CH, Barker JN, Detmar MJ, Brenchley PE, Griffiths CE: Interaction between genetic control of vascular endothelial growth factor production and retinoid responsiveness in psoriasis. J Invest Dermatol 2006;126:453-459.

9 Rottman JB, Smith TL, Ganley KG, Kikuchi T, Krueger JG: Potential role of the chemokine receptors CXCR3, CCR4, and the integrin alphaEbeta7 in the pathogenesis of psoriasis vulgaris. Lab Invest 2001;81:335-347.

10 Giustizieri ML, Mascia F, Frezzolini A, De Pità O, Chinni LM, Giannetti A, Girolomoni G, Pastore S: Keratinocytes from patients with atopic dermatitis and psoriasis show a distinct chemokine production profile in response to T cell-derived cytokines. J Allergy Clin Immunol 2001; 107:871-877.

11 Deleuran M, Buhl L, Ellingsen T, Harada A, Larsen CG, Matsushima $\mathrm{K}$, Deleuran B: Localization of monocyte chemotactic and activating factor (MCAF/MCP-1) in psoriasis. J Dermatol Sci 1996;13:228-236.

12 Tugues S, Fernandez-Varo G, Muñoz-Luque J, Ros J, Arroyo V, Rodés J, Friedman SL, Carmeliet P, Jiménez W, Morales-Ruiz M: Antiangiogenic treatment with sunitinib ameliorates inflammatory infiltrate, fibrosis, and portal pressure in cirrhotic rats. Hepatology 2007;46:1919-1926.

13 Kasselman LJ, Kintner J, Sideris A, Pasnikowski E, Krellman JW, Shah S, Rudge JS, Yancopoulos GD, Wiegand SJ, Croll SD: Dexamethasone treatment and ICAM-1 deficiency impair VEGF-induced angiogenesis in adult brain. J Vasc Res 2007;44:283-291.

Alexander Stratigos

A. Sygros Hospital, I. Dragoumi 5

GR-16121 Athens (Greece)

Tel. +30 210725 8476, Fax +30 210723 9965, E-Mail alstrat@hol.gr 